\title{
ORGANIZATIONAL CLIMATE AND GENDER DIFFERENCES IN WORK ENGAGEMENT AMONG NON- TEACHING STAFF IN A NIGERIAN UNIVERSITY
}

\author{
ABIMBOLA A. AKANNI \\ Department of Psychology, Obafemi Awolowo University, Ile-Ife, Nigeria \\ (C) 2019 Abimbola A. Akanni
}

This is an open access article distributed under the Creative Commons Attribution-NonCommercial-NoDerivs license (http://creativecommons.org/licenses/by-nc-nd/3.0/)

DOI: $10.1515 /$ eras-2019-0006

\begin{abstract}
The paper examines the link between organizational climate and work engagement among the non-teaching staff of a Nigerian University. Participants consisted of 229 (F=46.7\%; Mean age $=45.7)$ non-teaching staff selected using stratified random sampling technique from non-teaching staff of the institution. Participants completed the Utrecht Work Engagement Scale and Organizational Climate Measure that were subjected to Pearson Product Moment Correlation and t-test analysis. Results revealed that organizational climate is related to work engagement among registry staff. It also showed that female employees were more engaged with their work than their male counterparts. The paper recommends the design of appropriate strategies and interventions to ensure that employees feel more engaged in their work-roles.
\end{abstract}

\section{Keywords}

gender, non-teaching staff, organizational climate, work engagement

\section{Introduction}

A higher institution of learning comprises both teaching and non-teaching employees. The teaching employees are responsible for the achievement of the main goals for the establishment of such institution, while the non-teaching act in advisory capacity. In other words, they are required to provide adequate support necessary for the achievement of the basic objectives, for its establishment by the academic staff members. Engaging one's whole being in the work activities is important than just being physically involved in the daily routine of provision of services. Work engagement is defined as "an active, positive work-related state that is characterized by vigor, dedication, and absorption" (Bakker, 2011). Vigor is a state that refers to high levels of mental strength and energy, while dedication on the other hand refers to the sense of being strongly committed to the work. Absorption is the state of being happily engaged in the work (Bakker, 2011). Bakker (2011) argues that work engagement positively relates to job performance, and that workers that perform well and are engaged in their work will be able to create their own resources, thus it would result in a positive gain spiral. Nevertheless, now it would be interesting to figure out what could cause workers to become engaged. It is assumed that employees that are engaged in their jobs will deliver their duties appropriately and in a timely manner. Therefore, it is necessary to understand factors that may enhance proper engagement with one's work. This study proposes that organizational climate may relate to employees' work engagement.

There is a causal link of good organizational climate and employee's engagement in an 
organization. Organizational climate refers to an "individual perceptions; recurring patterns of behavior, attitudes and feelings of employees" (Griffin, 2014). It reflects the perceived psychological impact of the work environment on employees' wellbeing. Organizational climate has been reported to relate to work engagement (Chaudhary, Rangnekar \& Barua, 2014; Ancarani, Di Mauro \& Giammance, 2019). However, gender may play a role in the way and manner in which employees engage in their work.

Studies on gender differences in work engagement is scanty and with conflicting findings. For instance, while Gulzar and Teli (2018) reported that the level of work engagement for female academics is significantly better than their male counterparts, Vorina, Simonic and Vlasova (2017) found no difference between male and female employees in their level of work engagement. In an unrelated manner, Tshilongamulenzhe and Takawira (2015) found equal level of engagement in both male and female employees in the discharge of their duties. From the foregoing, it proposes that organizational climate relates to employees' work engagement among non-teaching staff. It is also hypothesized that male employees will be more engaged with their work than their female counterparts.

\section{Methods}

\section{Participants}

This study was conducted among the non-teaching staff in Obafemi Awolowo University, IleIfe, Nigeria. The institution is one of the first-generation universities with most of non-academic staff being recruited from a traditional ancient city of Yoruba land. It is assumed that their communal orientation will enable appropriate support system necessary for the smooth running of the institution. Participants consisted of 229 persons ( $\mathrm{F}=46.7 \%$; Mean age $=45.7$ years), that were recruited from the non-teaching staff of the university, using the stratified random sampling technique. Administrators (non-teaching staff) at the various faculties and departments in the institution were excluded from the study. The demographic characteristics of the participants are presented in Table 1.

\section{Measures}

Work Engagement: Information on the extent to which participants are engaged with their work was accessed using the 9-items short version of the Utrecht Work Engagement Scale developed by Schaufeli, Bakker and Salanova (2006). It has three dimensions: vigor, dedication and absorption. The response format ranges from never (0) to always (6). The internal consistency (Cronbach's alpha) of the UWES-9 varied from 0.85 (vigor), 0.83 (dedication) and (0.75) absorption.

Organisational Climate: Participant's perceived organizational climate was measured through a 16-items scale base upon Quins and Rohrbaugh's competing model and developed by Patterson et al. (2005). The response pattern is (1) = strongly disagree, $(2)=$ disagree, $(3)=$ undecided, (4) = agree, (5) = strongly agree. The internal consistency estimated using (Cronbach's alpha) the scales has values that are above 0.73 as reported by Patterson (2005). A coefficient of correlation between the two occasions was found to be 0.82 for reflectivity, 0.77 for innovation and 0.85 for outward focus. A convergent validity of 0.58 was obtained by Brown and Leigh (1996), indicating a moderate validity for the instrument.

\section{Procedure}

Approval for conducting the research was secured from relevant authorities. Participants signed the informed consent form and were ensured of anonymity and confidentiality of their 
responses. In addition, they were informed that they are free to withdraw their participation at any stage of the study when they feel so. Administration of questionnaire took place in their respective offices. The questionnaire has 25 items, which lasted 30 minutes to complete. Out of the 250 copies of the questionnaire that were administered, 229 were recovered, representing $91.6 \%$ return rate.

\section{Data Analyses}

Responses from the participants were coded and subjected to statistical analyses using the IBM SPSS (version 25). Specifically descriptive statistic such as percentage and mean were used to describe the participants, while inferential analysis such as Pearson Product Moment Correlation was utilized to investigate the relationship between organizational climate and work engagement. Gender differences in work engagement were determined using the independent t-test.

\section{Results}

The results of the data analysis are in two categories; the descriptive statistical analysis results and the results of the hypotheses testing. The results are presented in the tables below.

Table 1: Respondent's demographic characteristics

\begin{tabular}{llll}
\hline Variable & Level & Frequency $(\mathbf{n = 2 2 9})$ & $\begin{array}{l}\text { Percentage } \\
(\mathbf{\%})\end{array}$ \\
\hline Sex & Male & 122 & 53.3 \\
& Female & 107 & 46.7 \\
Religion & Muslim & 32 & 14.0 \\
& Christian & 192 & 83.8 \\
Years of experience & Traditional & 5 & 2.1 \\
& $0-9$ & 79 & 34.5 \\
& $10-19$ & 68 & 29.7 \\
& $20-29$ & 46 & 20.1 \\
\hline
\end{tabular}

Table 2: Correlation between organizational climate and work engagement

\begin{tabular}{lccccc}
\hline \multicolumn{1}{c}{ Variable } & $\overline{\boldsymbol{x}}$ & SD & N & r & P-value \\
\hline Organizational climate & 55.36 & 9.06 & 229 & $.210^{* *}$ & .001 \\
Work engagement & 73.36 & 13.45 & 229 & & \\
& & & & & \\
\hline
\end{tabular}

The result of the correlation analysis on the Table 2 showed a significantly positive relationship between organizational climate and work engagement $(r=0.210, p<.05)$ among non-teaching staff. The result indicates that the non-academic staff tends to be more engaged in their work when they perceive that the psychological impact on the work climate is more favorable. 
Table 3: Independent t-test comparison of male and female on work engagement

\begin{tabular}{lllllll}
\hline Group & N & $\overline{\boldsymbol{X}}$ & SD & df & t & p-value \\
\hline Male & 122 & 71.19 & 13.70 & 227 & & \\
Female & 107 & 75.83 & 12.77 & & -2.637 & .009 \\
Total & 197 & & & & & \\
\hline
\end{tabular}

Results of the t-test analysis revealed that there was a significant statistical difference between the mean of male $(\bar{X}=71.19, \mathrm{SD}=13.70)$ and that of female $(\bar{X}=75.83, \mathrm{SD}=12.77)$ non-academic staff on work engagement $\{\mathrm{t}(227)=-2.637, \mathrm{P}<.05\}$. The findings suggested the female nonacademic staff tends to have better work engagement than their male counterparts.

\section{Discussion of findings}

The aim of this paper was to examine the relationship between organizational climate and work engagement as well as ascertain gender differences in work engagement among registry staff in a Nigerian first generation university.

Findings from the study revealed significantly positive relationship between organization climate and work engagement. The results indicate that non-academic staff tends to be more engaged in their work when the organizational climate is more favorable. This finding agrees with previous studies (Chaudhary, Rangnekar \& Barua, 2014; Ancarani et al., 2019) that established a link between organizational climate and work engagement. Plausible explanation may be due to the regularity in the work environment prevailing in the Nigerian university as well as the recruitment pattern.

Gender differences were also found in the extent to which non-teaching staff engage with their work, that is, females non-academic staff tend to have better work engagement than their male counterparts. This supports the position of Gulzar and Teli (2018) who reported that work engagement level of female academicians was significantly better than their male counterparts. However, it contradicts the finding of Vorina, Simonic and Vlasova (2017) who argued that no significant difference exists between male and female employees in their level of work engagement. Therefore, the study concluded that organizational climate relates to work engagement and these differ significantly between male and female non-academic staff.

\section{Recommendations}

Since this study establishes that organizational climate relates to work engagement, the following recommendations may be useful for relevant stakeholders in the study.

- Organizations should consequently design the most appropriate strategies and interventions to ensure employees feel more engaged in their work-roles.

- Organizational management should be properly oriented on how formal organizational support, implementation of work policies, proper supervisory and teamwork affect employees' levels of job engagement.

- Since women show more engagement to their jobs than their male counterparts, management or superiors need to understand the different work climate that suit both parties best, in order to encourage a high level of work engagement and productivity.

\section{Conflict of Interest}

The author report no conflict of interest. 


\section{REFERENCES}

Ancarani, A. Di Mauro, C. \& Giammanco, M. D. (2019) Linking Organizational Climate to Work Engagement: A Study in the Healthcare Sector, International Journal of Public Administration, 42:(7), 547-557. http://doi.org/10.1080/01900692.2018.1491595

Bakker, A. B. (2011). An Evidence-Based Model of Work Engagement. Current Directions in Psychological Science, 20(4), 265-269. http://doi.org/10.1177/096372141141453

Brown, S. P. \& Leigh, T. (1996). A new look at psychological climate and its relationship to job involvement. Journal of Applied Psychology 81(4): 358-68. http://doi.org/10.1037/0021-9010.81.4.358

Chaudhary, R., Rangnekar, S. \& Barua, M. K. (2014). Organizational climate, climate strength and work engagement. Procedia - Social and Behavioural Sciences, 133: 291-303. http://doi.org/10.1016/j.sbspro.2014.04.195

Gulzar, S. \& Teli, M. R. (2018). Gender and work engagement: A study of academic staff in higher education. Arabian Journal of Business and Management Review, 8(2), 1-3

Patterson, M. G., West, M. A., Shackleton, V. J. Dawson, J. F., Lawthom, S. M., Maitlis, A. et al. (2005). Validating the organizational climate measure: links to managerial practices, productivity and innovation. Journal of Organisational Behaviour, 26, 379-408. http://doi.org/10.1002/job.312

Quinn, R. E., \& Rohrbaugh, J. (1983). A Spatial Model of Effectiveness Criteria: Towards a competing Values Approach to Organisational Analysis. Management science 29 (3), 363-377

Salanova, M., Del Líbano, M., Llorens, S., \& Schaufeli, W. B. (2014). Engaged, Workaholic, Burned-Out or Just 9-to-5? Toward a Typology of Employee Well-being. Stress and Health 30 (1), 71-81.

Schaufeli, W. B., Bakker, A. B., \& Salanova, M. (2006). The measurement of work engagement with a short questionnaire. A cross-national study. Educational and Psychological Measurement, 66 Publications http://doi.org/10.1177/0013164405282471

Tshilongamulenzhe, M. C., Takawira, N. (2015). Examining the gender influence on employees' work engagement within a South African University. Risk governance \& control: Financial markets \& institutions, 5(2-1), 110-119. http://dx.doi.org/10.22495/rgcv5i2c1art5

Vorina, A., Simonič, M., \& Vlasova, M. (2017). An analysis of the relationship between job satisfaction and employee engagement. Economic Themes, 55(2), 243-262 